\title{
INTO THE DARKNESS: DEEP CAVES IN THE ANCIENT NEAR EAST
}

\author{
MICHAEL FREIKMAN
}

Ariel University, Ariel and Hebrew University of Jerusalem, Jerusalem, e-mail: michel.freikman@mail.huji.ac.il

Received: $11^{\text {th }}$ July 2017, Accepted: $7^{\text {th }}$ January 2018

\begin{abstract}
In this paper I will present the assemblage of pottery vessels and objects of luxury dated to the Neolithic and Chalcolithic periods discovered in the Zarda Cave in Western Samaria, Israel. The context in which this assemblage was found is strongly reminiscent of other proto-historic depositions found in Israel. As determent of objects of value found in the deep and dark caves cannot be explained by means of burial offerings or regular hoards one most provide this remarkable phenomenon by a different theory. In this paper, I claim that these depositions were ritual in nature. They bear physical evidence for rituals performed by specially chosen members of the society, which we call today shamans. These caves were chosen due to their physical properties to become scenes for rituals of rites of passage in the course of which they experienced altered states of consciousness. In the course of time these caves have accumulated considerable social power becoming liminal monuments on the fringes of social landscapes in the local cultures. We may understand deep and dark caves as an element of pre-urban cosmology embedded into the local landscape, traces of which can be detected in much later traditions.
\end{abstract}

Keywords: Neolithic, Chalcolithic, Deep caves, Alternative states of consciousness, Israel

\section{INTRODUCTION}

Study of the processes that took place in the economic and social life of the Neolithic and Chalcolithic periods is crucial for understanding the development of human societies in the ancient Near East. One of the markers of the gradual development of stratification in human society is rapidly increasing complexity of the social landscape. The late prehistory of the ancient Near East is characterized by a steady increase in the complexity of the household, expressed by larger and more complex courtyard houses and the appearance of the first signs of administration. Settlements become larger and we witness organization of the communal space, such as streets, wells, sanctuaries and other communal features (Garfinkel \& Ben-Shlomo, 2009: 67-83). The emergence of public institutions accelerated the natural process of the appearance of arenas of economic and social power in the centers of settlements, frequently expressed by monumental architecture (Chapman, 1991). This process must have created stress between the center of the landscape, where most of the resources were concentrated, and the fringes, which were relatively poor in these resources. In archaeological publications it is usually the monuments or settlements in the central part of 
landscapes that are studied and discussed in detail, while the liminal areas of the same landscapes are often left out of the discussion. However, the liminal spaces located on the margins are no less important for the community's self-definition and for the distinction between members of the community and "the others" (Van Gennep, 1960). Natural landmarks and man-made monuments defining the borders of the territories of states and settlements are not uncommon in both the ancient and the modern worlds. These monuments can take various forms and mark borders between territories of different kinds (Van de Noort, 2008: 487): for example, they can mark a border between two social entities, or between land and water bodies, or between the surface and the chthonic realm. They can also mark the limes not only between two groups of the living, but also between the realm of the living and that of the dead, i.e. the Netherworld (Beckman, 2013). Tombstones, ancient massebot and mortuary caves in general can also be interpreted as liminal monuments marking the place of contact with the world of the dead (Rowan \& Ilan, 2012: 102-103). A better understanding of such liminal phenomena can in turn help us to acquire a better understanding of the societies themselves. In this short paper, I will present the case study of the Zrada cave, compare it to other similar liminal spaces of the late prehistoric landscape in Israel and propose an explanation for their existence and function.

\section{THE ZRADA CAVE: DATA}

A cave located near Khirbet Zrada (Fig. 1) was recently reported by a speleology team directed by S. Shipitsin and subsequently surveyed in 2015 by the author and again by R. Porat on behalf of the Institute of Archaeology of the Hebrew University of Jerusalem (license no. 12/2015). The numerous finds made during the surveys are dated to various periods, from the Pottery Neolithic to modern times. The full data will be published elsewhere, and here we concentrate on the presentation and discussion of the early material collected in the cave.

Fig. 1: Location of Zrada cave and sites mentioned in the paper (map prepared by M. Frumin)

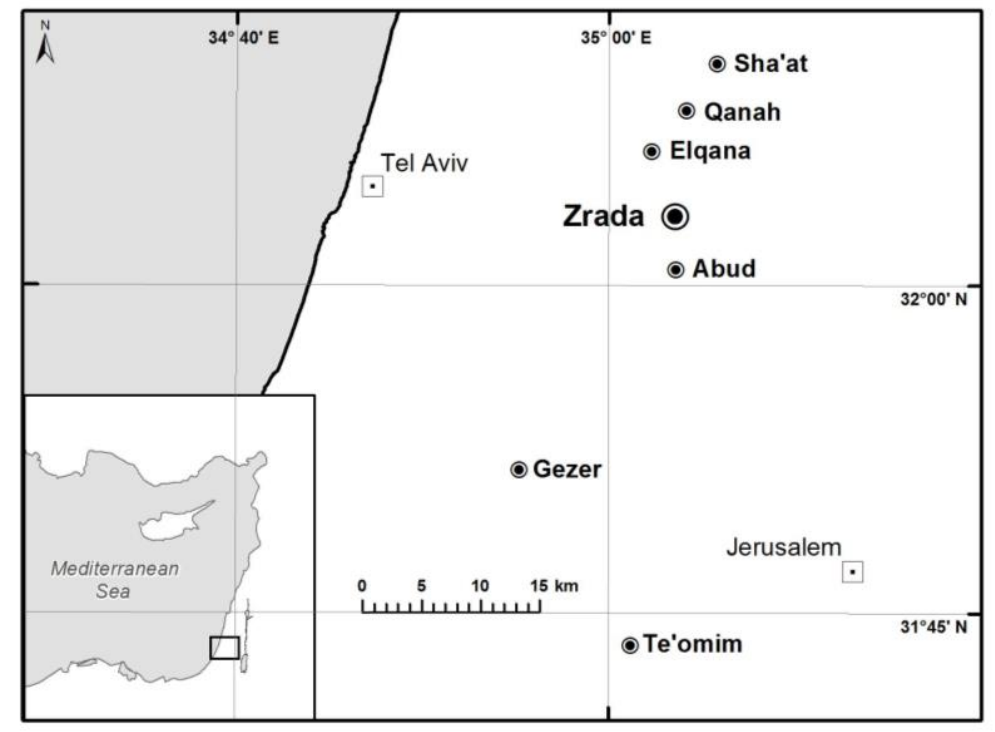


The Zrada cave (Fig. 2) is located on the western slopes of the Samaria plateau. It is a deep karstic cave reaching a depth of some $40 \mathrm{~m}$ and the total length of its passages exceeds $600 \mathrm{~m}$. Access to the cave is through a single opening (Fig. 3). This is a vertical shaft more than six meters in depth, making access very difficult and in fact impossible without ropes, ladders or other special equipment.

Fig. 2: Kh. Zrada viewed from the opening of the Zrada cave

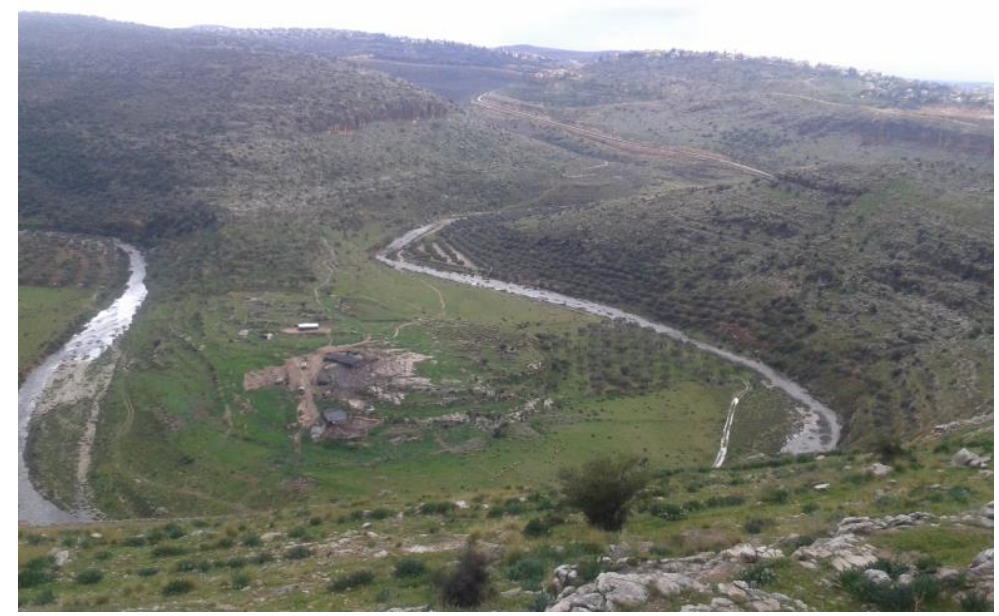

Fig. 3: Entrance into the cave

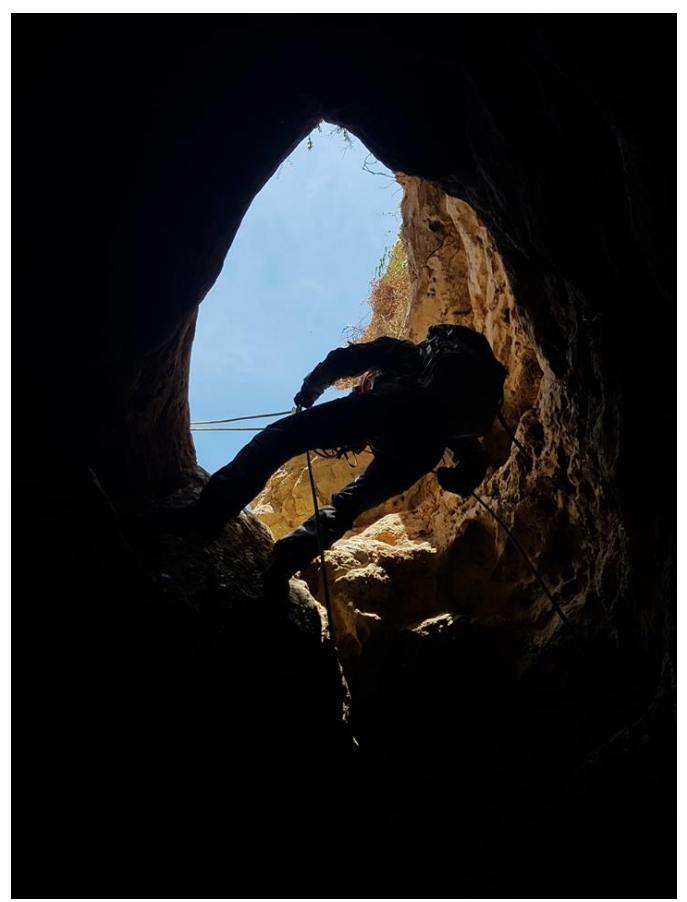


The cave's rooms and passages are located on three main levels connected by almost vertical shafts, making access to the lower levels challenging (Figs. 4, 5). Only the upper level is lit to some extent by sunlight through the access shaft, while the lower levels are in total darkness. All the passages inside the cave are natural and there is no evidence for the quarrying of artificial passages (as in the refuge caves of the Bar Kokhba period). However, a few architectural features were recorded inside the cave. The upper level contains a number of retaining walls that could possibly have supported a few makeshift constructions used as dwellings.

\section{Fig. 4: Plan of the Zrada cave}

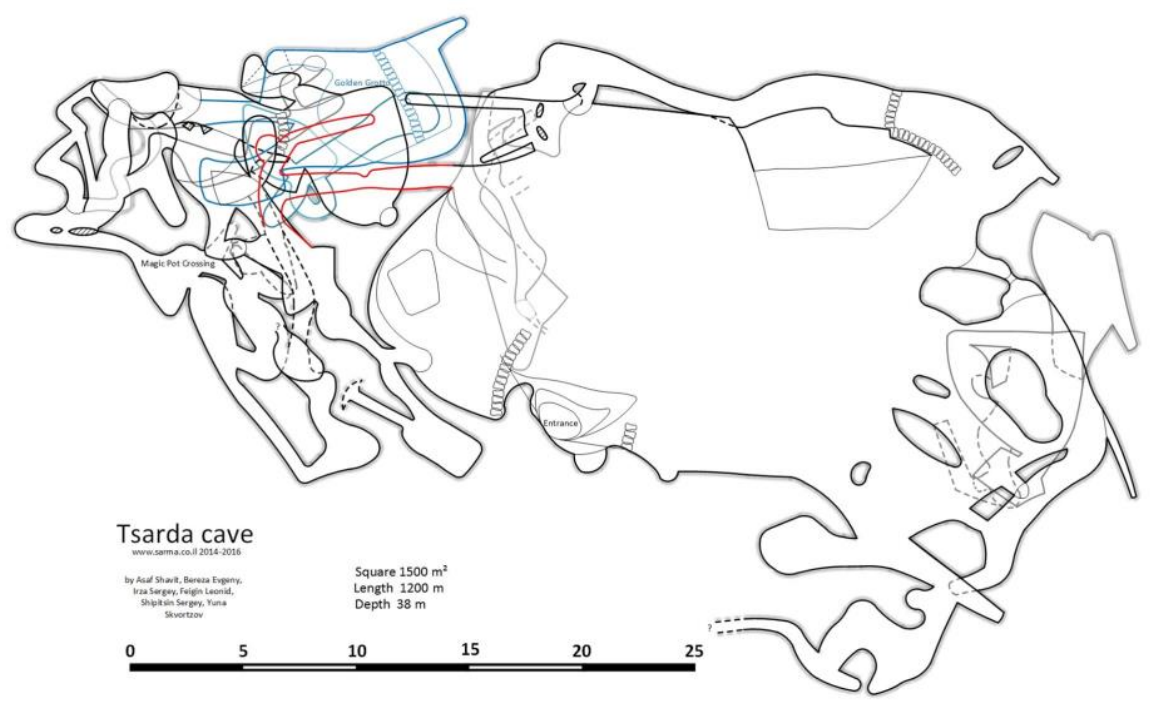

Fig. 5: Section of the Zrada cave. Depositions of pottery are marked with red circles. Deposition of the golden beads is marked with a red star.

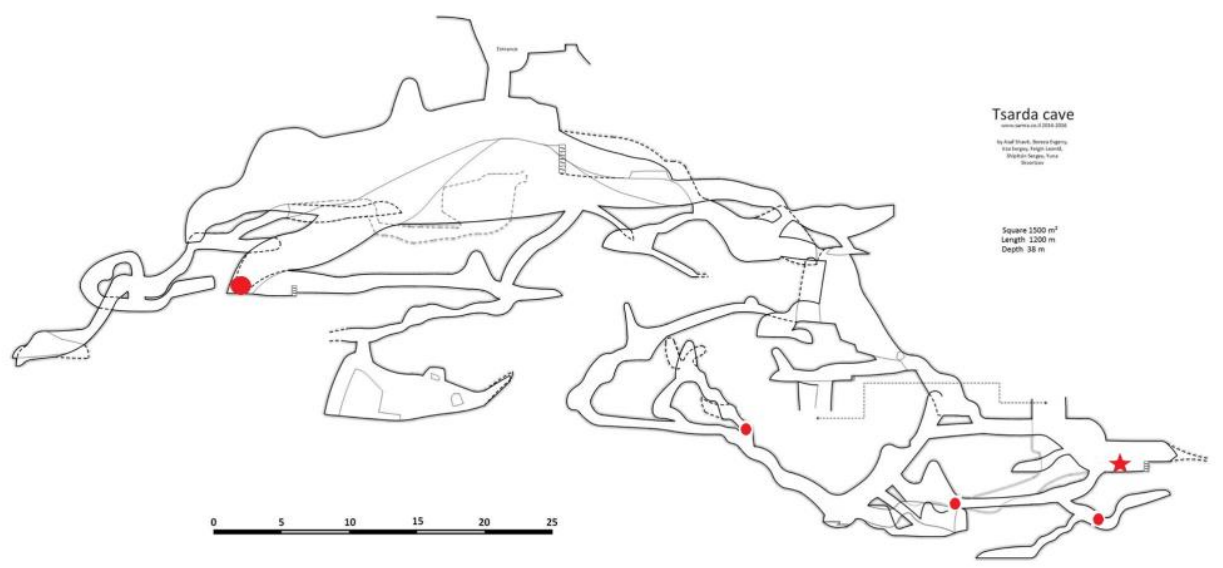


The dark part of the cave lacks any architectural features, with a single exception: in room 324 , at a depth of some $37 \mathrm{~m}$ below the surface, the floor is partially paved by large flat slabs placed in the central part of the room (Fig. 6, 7).

Fig. 6: Pavement L.133. Golden beads were found between the stones of the pavement. (Photo by A. Frumkin)

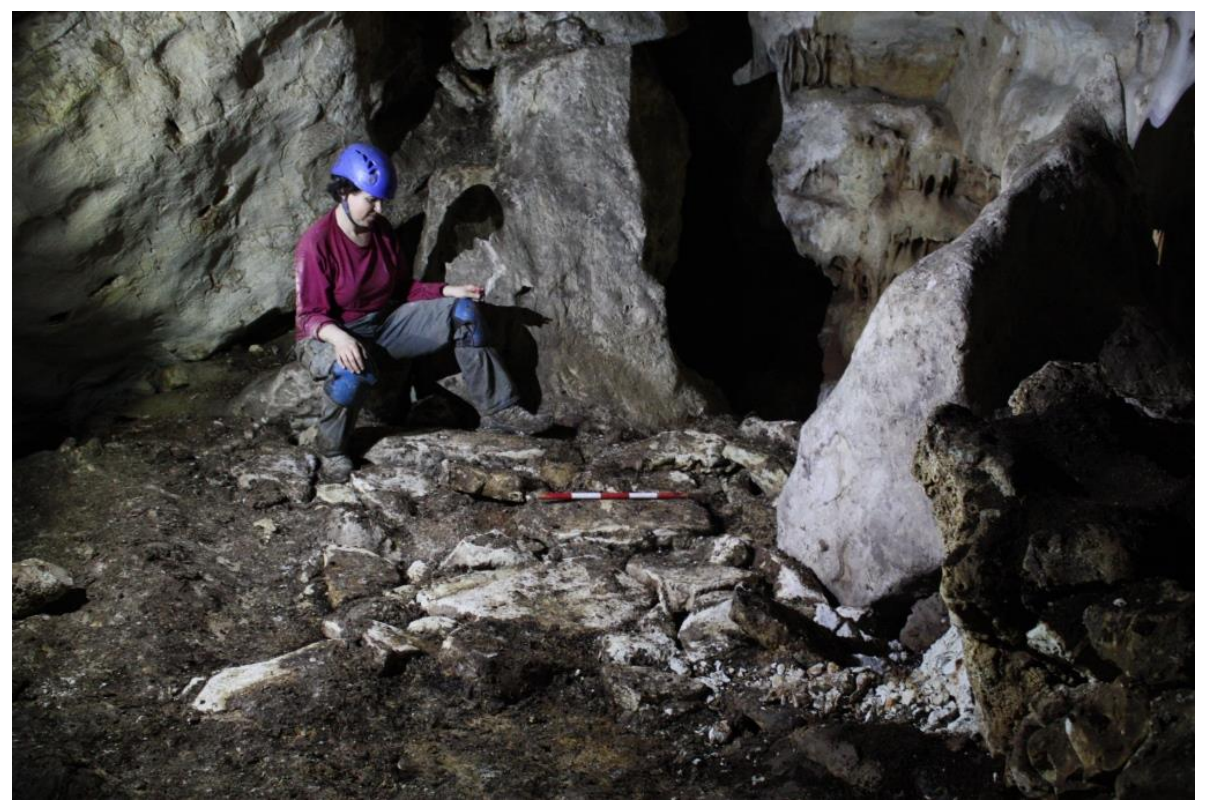

The finds discovered in the context of this pavement will be discussed below. As mentioned above, finds dated to various periods, from the Pottery Neolithic to modern times, were found in different parts of the cave. However, there seems to be a pattern in the distribution of the finds across the cave. Finds dated to the historical periods (Iron Age and later), such as a Herodian lamp and a cache of three basalt three-legged bowls, were found mostly in the upper (lit) parts of the cave. A few small fragments of later pottery were found in the lower levels as well, but they were presumably washed down by alluvial water. No complete vessels or large fragments of vessels were found in the dark parts of the cave. 


\title{
Fig. 7: Drawing of the pavement
}

\author{
מערת צרדה - אולם F \\ $155953 / 162096$. נ.

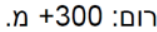 \\ מיפוי: בועז לנגפורד, מיקה אולמן, רועי פורת מלת \\ 2015 מלחיר \\ $-5 \mathrm{C}-$ \\ מפה
}

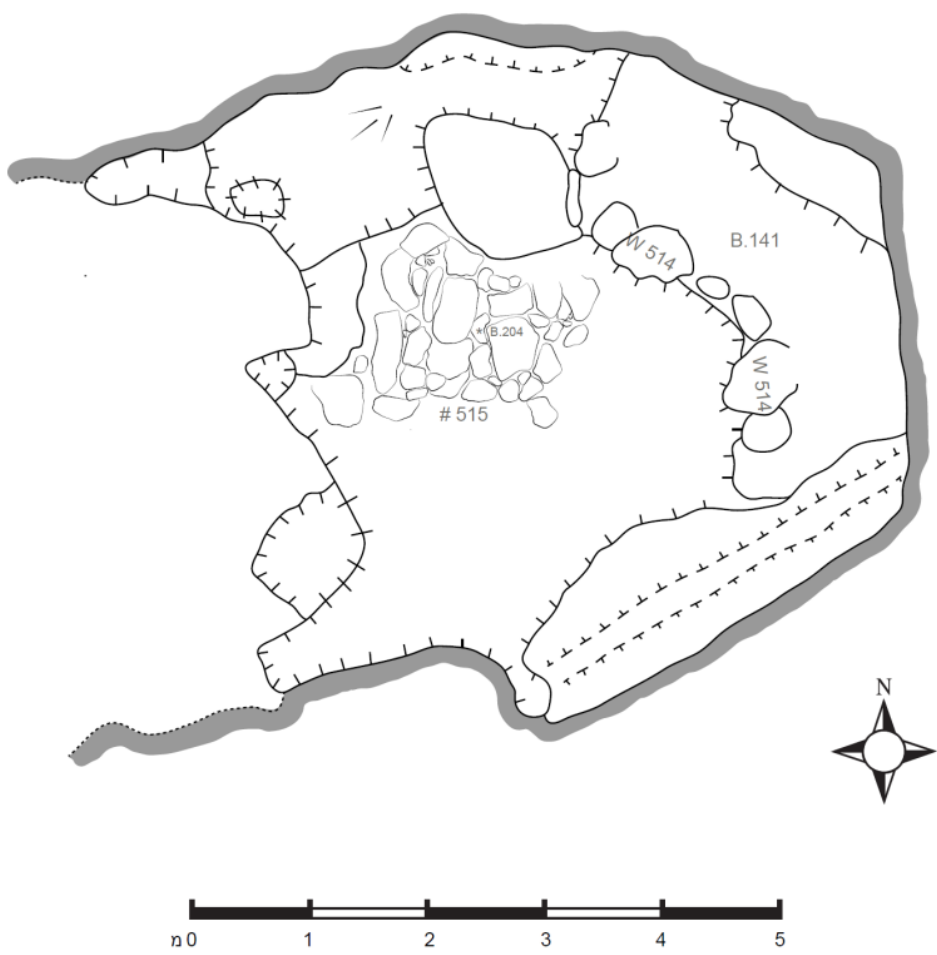

The finds in the lower, dark parts of the cave were different. They include:

1. A large complete jar (Figs. 8:1, 9) decorated with herringbone pattern and red paint typical of the Yarmukian culture and a small jarlet (Figs. 8: 2, 10) decorated with herringbone pattern, both dated to the Pottery Neolithic period. In addition, a pierced handle typical of the period was found in L. 132 (Fig. 8:3). A few more large fragments of storage vessels of different sizes found behind rocks should be dated to this period as well. 
Fig. 8: Yarmukian pottery found in the Zrada cave

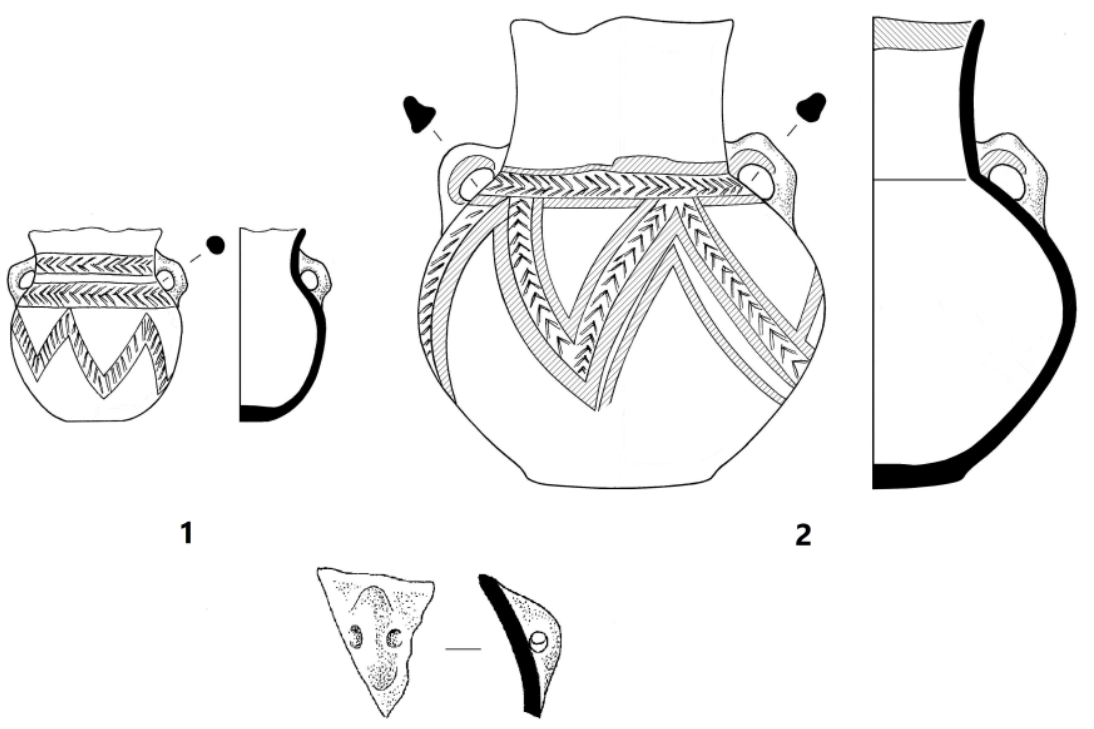

3

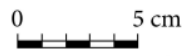

Fig. 9: Yarmukian jar (Photo by T. Rogovsky)

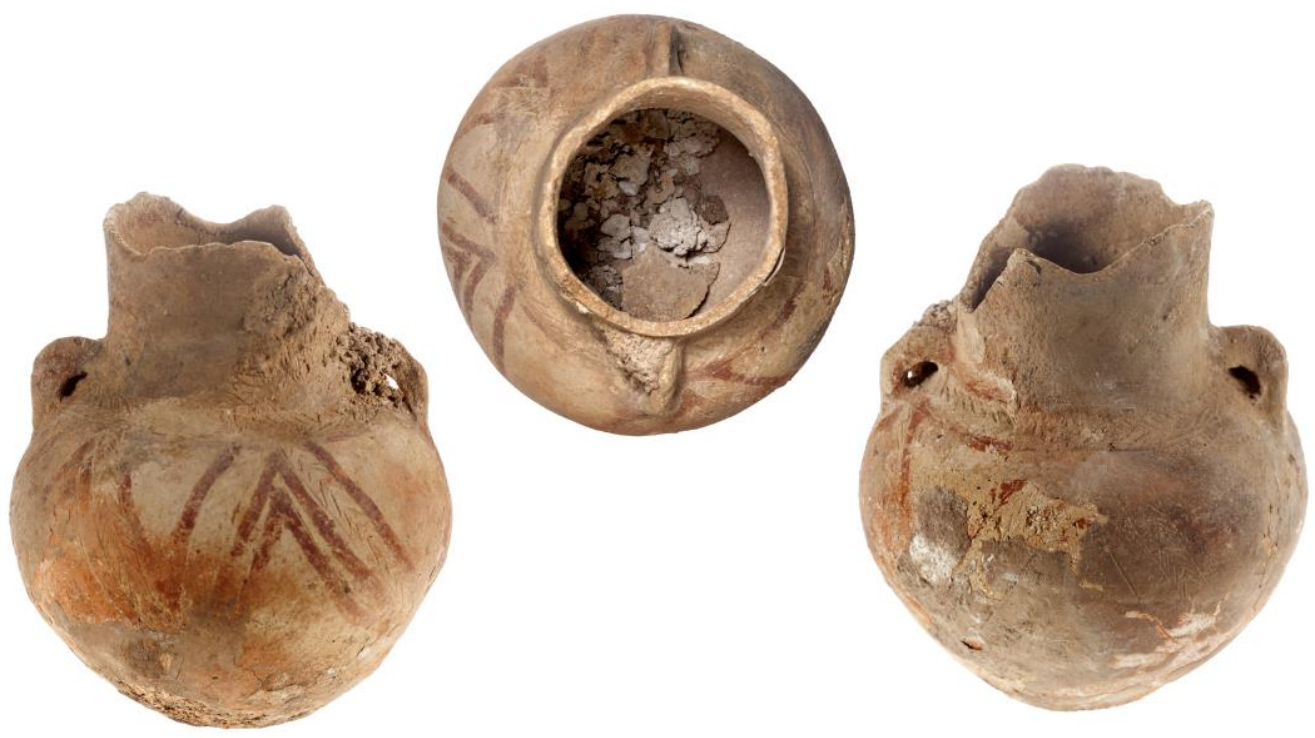




\section{Fig. 10: Yarmukian miniature jar in the context (Photo by A. Frumkin)}

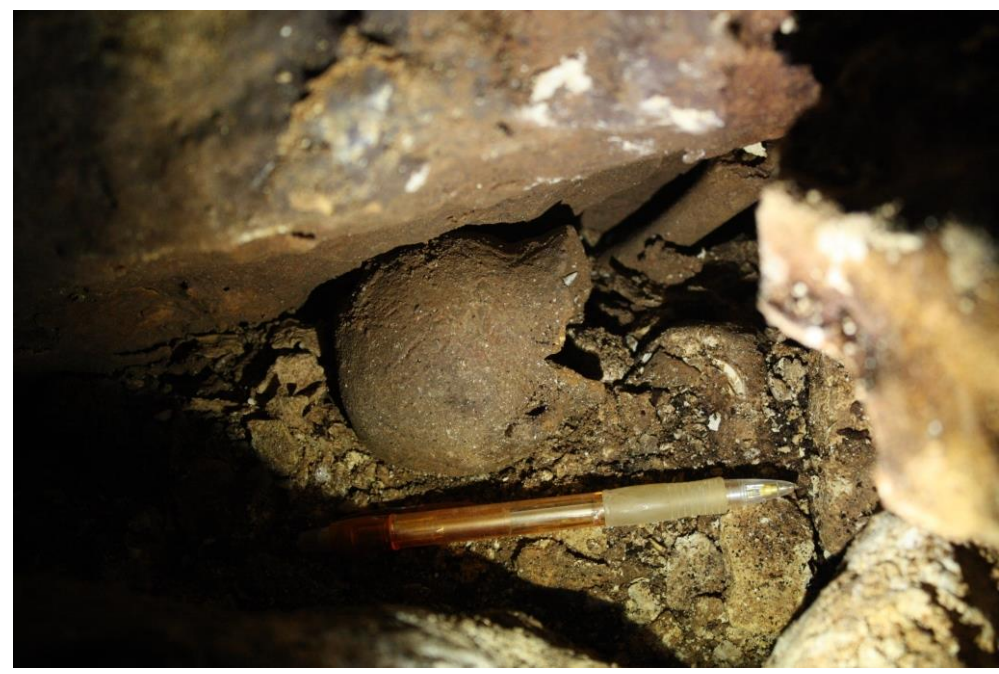

2. Fragments of at least six Chalcolithic bowls, including simple bowls with or without "lipstick" decoration and small and large V-shaped bowls (Fig. 11).

\section{Fig. 11: Bowls}

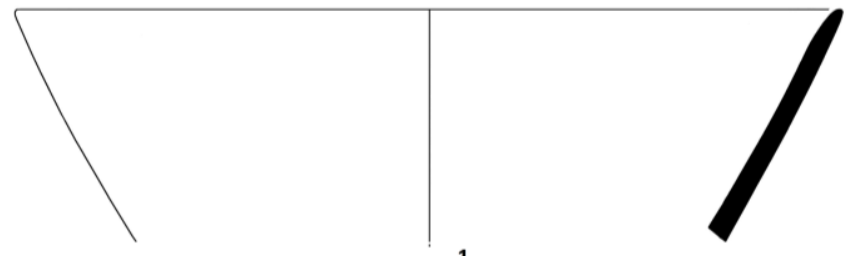

1

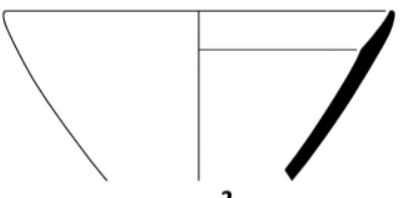

2

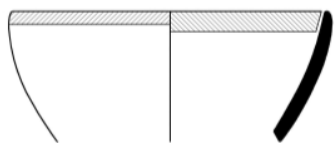

3
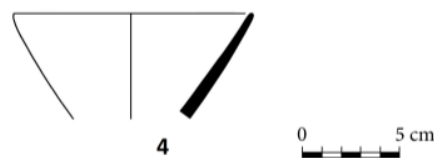

3. Two large fragments of Chalcolithic holemouth jars (Fig. 12:1-2).

4. A large fragment of a Chalcolithic churn (Fig. 12:3). 
Fig. 12: Closed vessels
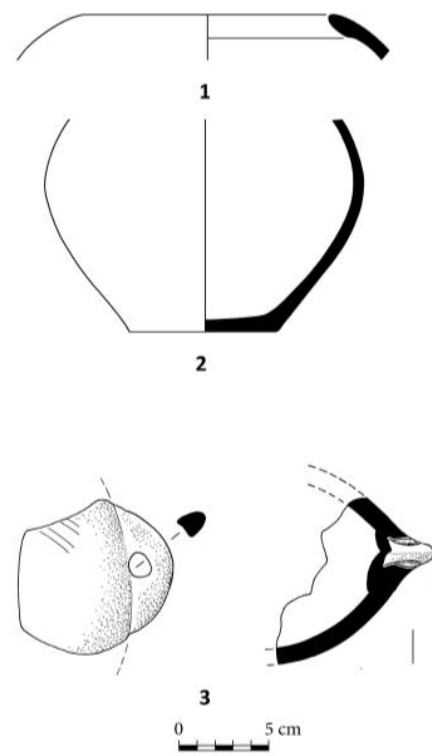

5. A cache found between the stones of pavement L. 133 is especially noteworthy. It consists of three beads, two of metal and one of stone (possibly carnelian) (Figs. 13, 14). The metal beads are made from an alloy of gold and silver that is strikingly reminiscent of five of the gold rings found in the Qanah cave (see also below). They were not cast but prepared and finished by hammering. Tiny cracks that can easily be seen on the surface of these beads are the outcome of the craftsman's work.

Fig. 13: Golden and carnelian beads

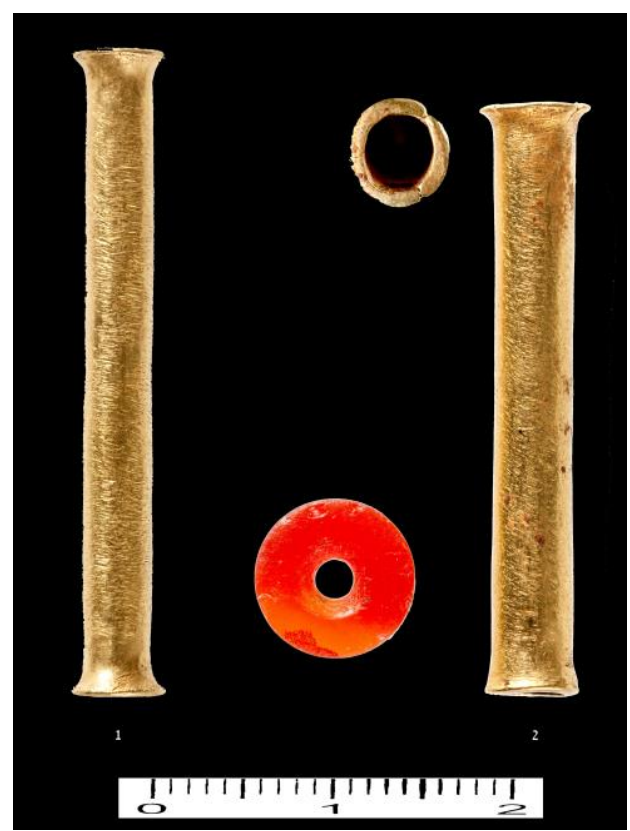




\section{Fig. 14: Drawing of the beads}

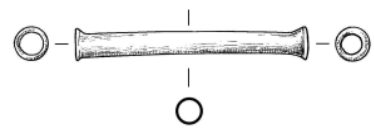

1
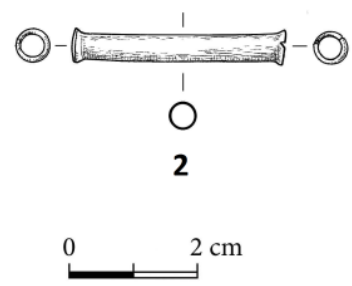

Most of these objects were found in the deep and dark parts of the cave. Moreover, many of them (both of the complete Pottery Neolithic vessels, some of the partially preserved storage jars, and the beads in room 321) were found deliberately tucked behind rocks or under the pavement, thereby preventing their discovery by casual visitors.

\section{Parallels}

The Zrada cave is not the first example of deliberate deposition of various objects in caves in our region in prehistoric times (Fig. 2). Several examples will be given here:

1. The famous cave in Qanah Stream was discovered and investigated in the 1980s (Gopher $\&$ Tsuk, 1996). This cave, located only a few kilometers from the Zrada cave and some $60 \mathrm{~m}$ deep, has yielded some of the most exciting finds ever discovered in Israel. Pottery Neolithic and Chalcolithic vessels were discovered at depths of dozens of meters below the surface. While some of these finds could be related to the Chalcolithic burials, others were interred there as deposits in their own right. One find is especially noteworthy: eight rings made of gold and electrum were found in a room in which a Chalcolithic burial as well as a deposit of Pottery Neolithic pottery vessels were found. Remarkably, the alloy of some of these rings is almost identical to that of the beads found in the Zrada cave (Gopher \& Tsuk, 1996: 165175).

2. Another intentional deposit of complete Pottery Neolithic jars was recently found in the Elqana cave during a salvage excavation in the area. Most of them are small, in one case barely reaching a diameter of $5 \mathrm{~cm}$, and they are most probably votive vessels (Zissu et al. 2014).

3. The Te'omim cave, surveyed in the first half of the twentieth century, yielded a number of Pottery Neolithic and Chalcolithic objects (Neuville, 1930).

4. Several Chalcolithic and Bronze Age objects, including a complete mace head, were found in the deepest level of the Abud cave (Langford et al., 2011: 72-73).

5. The numerous votive pottery vessels found in the Sha'at cave are dated to the Chalcolithic and Early Bronze Age (Freikman \& Ilan, forthcoming).

6. Of particular interest is the famous sanctuary with a row of stelae found in Gezer more than a century ago and termed a "high place" by Macalister. While the stelae themselves may date from the Middle Bronze Age, the sanctuary in general may originate in a much earlier period (Macalister, 1912: 377-408). Indeed, Macalister also reported a cave located directly under this compound in which a cache of several dozen small votive vessels dated to the Early Bronze I Age was found (Macalister, 1911: 107-111; Ben-Ami, 2008). Based on the material presented in this paper, we may speculate that this deposit belongs to the phenomenon discussed here, although the nature of the cave itself is different. 
This is by no means a full list of parallels found in the caves of the Southern Levant, and we may presume that as research continues more finds of this kind will be published in the near future. Apparently, we can speak of a widespread phenomenon in the late prehistory of the Southern Levant: intentional interment of objects, some of them of considerable value, in deep and dark caves.

Taking into account the numerous deposits listed above that were found in similar contexts, we are clearly dealing with more than a coincidence: this is a real phenomenon distributed across the region and possibly far beyond it, which demands an explanation. The cases presented above share the following characteristics:

a. The deposits are dated to the Pottery Neolithic, Late Chalcolithic and Early Bronze Age. No later assemblages in similar contexts are so far attested.

b. The deposits were left in barely accessible parts of the caves; in many cases, one must literally crawl through very narrow passages or use special equipment in order to access these locations. Moreover, most of these caves are almost undetectable in the surrounding landscape. The combination of these factors makes "unauthorized" access to the deposit area highly unlikely.

c. All of these deposits were found in deep and dark parts of the caves, and hence must be distinguished from objects and caches deposited in later periods in the lit and/or relatively easily accessed upper parts of the same caves.

d. Many of the deposited pottery vessels are small in size. They are of little use as receptacles, and therefore should be defined as votive vessels.

These observations demonstrate the difficulty of explaining this phenomenon in functional terms. Objects of considerable value were transported over distances of many kilometers from the place of their production/storage, only to be concealed deep underground. Access to these deposits was by no means easy and even today requires a substantial effort, making the possibility of their planned recovery and retrieval at a later date highly improbable. Only rarely, if at all, can these interments be related to burials. They were certainly placed there on their own, but at the same time they cannot be regarded as hoards, for they were never intended to be retrieved by the people who deposited them. Therefore, since it is hard to suggest a reasonable mundane explanation for this phenomenon, a different interpretation must be proposed for this overall mass of data. More precisely, I propose that these were ritual deposits of some kind. Due to the very nature of the underground spaces, they have remained hidden from the eyes of passersby as well as scholars, making their study a very hard task. However, even with these limitations the evidence for interaction of human beings with dark caves as sacred loci in general, and with interments there of valuable objects in particular, is well attested in the Old World.

\section{Parallels from the Old World}

I will present a limited number of examples to illustrate the prevalence of this phenomenon in space and time:

1. Human beings have visited deep and dark caves with intentions other than the mundane since the Paleolithic period; beautiful mural paintings with realistic depictions of zoomorphic figures that may be interpreted as shamans wearing masks are well known throughout Western Europe (Sieveking, 1979; Leroi-Gourhan, 1984; Clottes \& Lewis-Williams, 1998).

2. Malta is famous for its Neolithic subterranean sanctuaries, which were possibly related with the idea of passage to the Netherworld in the final stage of the life cycle and may be regarded as a kind of gateway to the chthonic world. These sanctuaries are characterized by the ritual deposits found inside them (Skeates, 1991: 90-91). 
3. The peak sanctuaries of Bronze Age Crete are located within caves on mountain summits, some of them deep and dark, where rich evidence for Minoan ritual activities was found (Jones, 1999). Some of them retained their sanctity during later times, such as the Arkolokhori cave (Hazzidakis, 1913) or the Psychro cave, which was identified as the birthplace of Zeus (Cook, 1925: 925-928). Later on, oracles all over the Greco-Hellenistic world performed their divination rituals in similar deep and dark caves, sometimes with poisonous gas emitting from the earth (Ustinova, 2009).

4. The cave located under the stelae sanctuary found in Gezer was mentioned above. Macalister compared the cave found there to the classical Greek $\alpha \hat{\alpha} \delta \tau o v$ - the place where oracles performed their rituals (Macalister, 1912: 384).

5. It is noteworthy that remnants of the sanctity of the caves survived in later times and still persist in monotheistic religions even today. For instance, Rabbi Bar Yochai is believed to have written the renowned mystical Book of Zohar after spending many years in a cave. Christian tradition locates many of the Old and New Testament traditions inside various caves in the Near East. Many Byzantine monks lived in the darkness of natural or artificial caves, and millions of Orthodox pilgrims to the Holy Land still visit holy places relating to the biblical tradition and located inside caves. It is possible that the pilgrims' veneration of these places is an echo of long-forgotten rituals performed in the caves in the biblical and prehistoric periods, which were absorbed into Christian tradition through the Greek or Byzantine culture. The tradition of caves as gates into Hades is even mentioned in the Gospels: while visiting the city of Caesarea Philippi at the foot of Mount Hermon, Jesus turns to Peter with the words "And I tell you that you are Peter, and on this rock I will build my church, and the gates of Hades will not overcome it" (Matthew, 16:18). It seems that "the gates of Hades" mentioned by Jesus are not merely a metaphor: the most important focal point in the city was a cave which in local belief was the birthplace of the god Pan, and was also generally believed to be a gate to the Netherworld.

\section{DISCUSSION}

Apparently, the use of caves for cultic activities has persisted since the earliest periods of the human career and up to the present. Caves related to various ritual activities are so widely attested in various cultures all over the world that the possibility of direct or even indirect cultural influence between them can be ruled out (for instance; Moyes, 2012). Thus, there must have been a very good reason why people from different regions repeatedly descended into these dark and dangerous places in order to perform ceremonies and leave pottery and valuable objects over such a long span of time. The text "Ištar's Descent and Resurrection" (Lapinkivi, 2010) may be enlightening to a scholar in search of these reasons. On her way to the deepest parts of the Netherworld, Ištar goes through seven gates leaving various elements of her clothing and jewelry in each of them in order to gain access to the next gate, eventually reaching her final destination after leaving all her possessions behind (Lapinkivi, 2010: 30). This version of the text is dated to the second millennium B.C., although its origins must be much older. This text shows that the problem of passage between the world of the living and the Netherworld was well known to the inhabitants of the ancient Near East and was addressed in the mythology. This story may throw light on the archaeological finds discovered in the subterranean spaces of late prehistory. However, the situation is complex. On the one hand, we see that this tradition is a good fit for the practice of sanctifying deep and dark caves in the Old World in general. On the other hand, such a wide distribution of this tradition through space and time cannot be explained by cultural or economic relations alone. 
Therefore, we must seek the solution to this problem at a cognitive or even deeper level, attempting to isolate a common denominator that enables us to propose a comprehensive explanation.

One answer to this problem may lie in the biological characteristics of the human brain itself and the way it is influenced by deep and dark spaces, no matter where and when they are encountered. The first phenomenon is a loss of orientation in space and time, which gradually intensifies as a person descends deeper into the cave. Even a descent of a few dozen meters from the entrance may severely affect the perception of space (Figs. 15-17).

The stress that this causes to the human brain is exacerbated by total (or almost total) darkness. Complete or partial sensory (particularly visual) deprivation experienced by a person for a span of time (which can differ from person to person) may trigger another phenomenon, altered states of consciousness (ASCs), which in their turn may cause a series of hallucinations that become more vivid and complex with time (Lewis-Williams, 2002a: 271; 2002b: 208-209; Sireteanu et al., 2008). After many years of study of these hallucinations in different cultures, a general model of the sequence of their appearance can be proposed. Lewis-Williams has defined it as a "three-stage model" based on both ethnographic observations and laboratory experiments:

a. An "entoptic" stage, when a shaman experiences visions of geometric figures. These figures are mostly not random but consist of a limited set of geometric figures: dots, zigzags, grids, nested catenary curves and meandering lines (Lewis-Williams 2002a: 126).

b. In the visions of the second stage, the shamans' brain "tries to make sense of the entoptic phenomena by elaborating them into iconic forms, that is, into objects that are familiar to them from their daily life" (Lewis-Williams 2002a: 127). In other words, our brain reproduces images of the everyday events that are embedded in our memory. Clearly, the large mammals that were the main object of the hunt, or in contrast the large predators that intimidated the members of Neolithic communities, could have provided such images, and consequently they appear frequently in prehistoric art.

c. The third stage is characterized by the most vivid and complex hallucinations. Moreover, various entoptic and iconic figures experienced earlier can merge into one another and take bizarre and unrealistic forms. For instance, subjects of experiments report on their gradual transformation into animals while under the influence of ASCs (Siegel and Jarwick 1975: 103-106). Particularly noteworthy is a vision that is often experienced between the second and third stages: a feeling of passing through a funnel, tunnel or vortex, very reminiscent of the near-death experience. This experience is frequently described by shamans as a hole through which the upper and lower realms can be reached. While the strict division of the whole process into three (or four) stages may be an oversimplification of the phenomenon, the general idea of the evolution of the hallucination from simple geometric images to complex scenes is confirmed by ethnographic observations independently made by other scholars (for instance Shannon 2002). As this model is defined by neurobiological processes occurring in the human brain, we may expect to find variations on this phenomenon (depending on the cultural factors inherited by an individual) among different ethnic groups and different periods. Integrating this model into the cosmology of a given shamanistic society gives us a better understanding of the cosmology and in particular the way it is reflected in the archaeological evidence. 
Fig. 15: A person standing at the entrance to a cave as seen from the distance of three meters

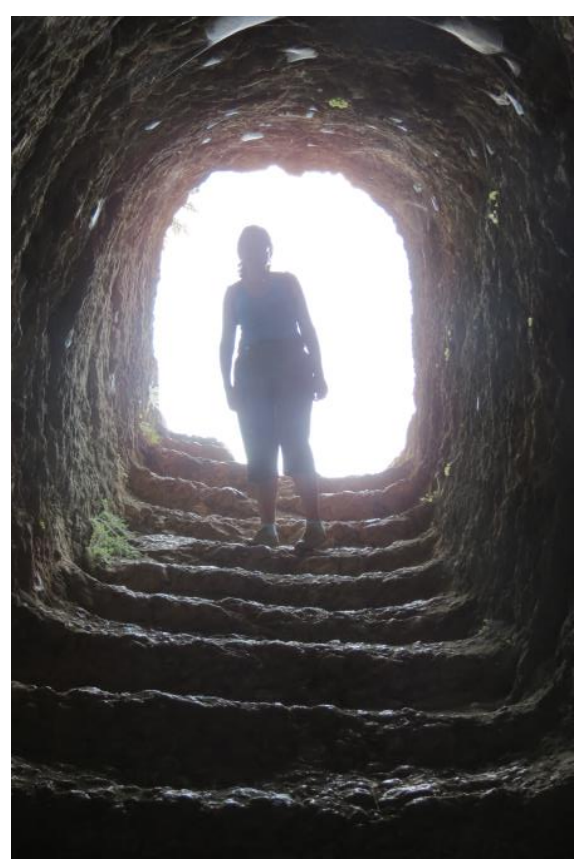

Fig. 16: A person standing at the entrance to a cave as seen from the distance of 15 meters

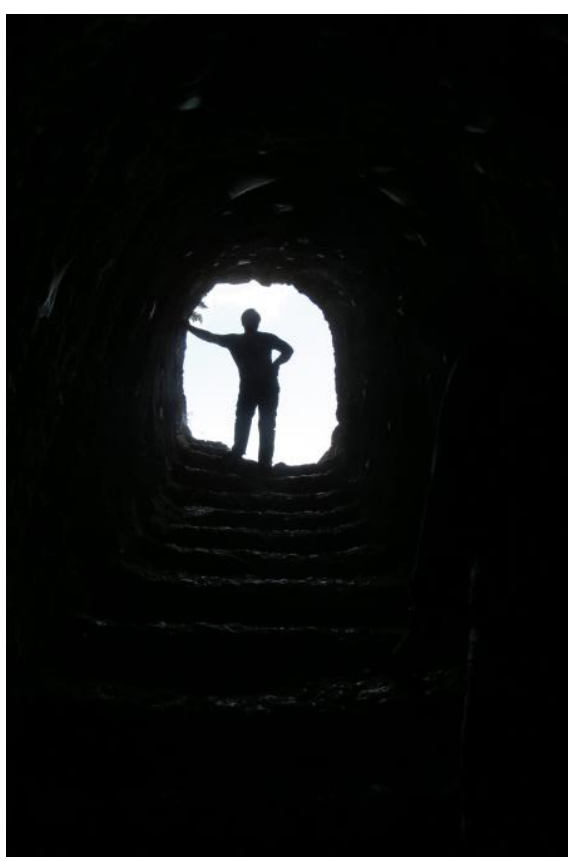

Fig. 17: A person standing at the entrance to a cave as seen from the distance of 50 meters

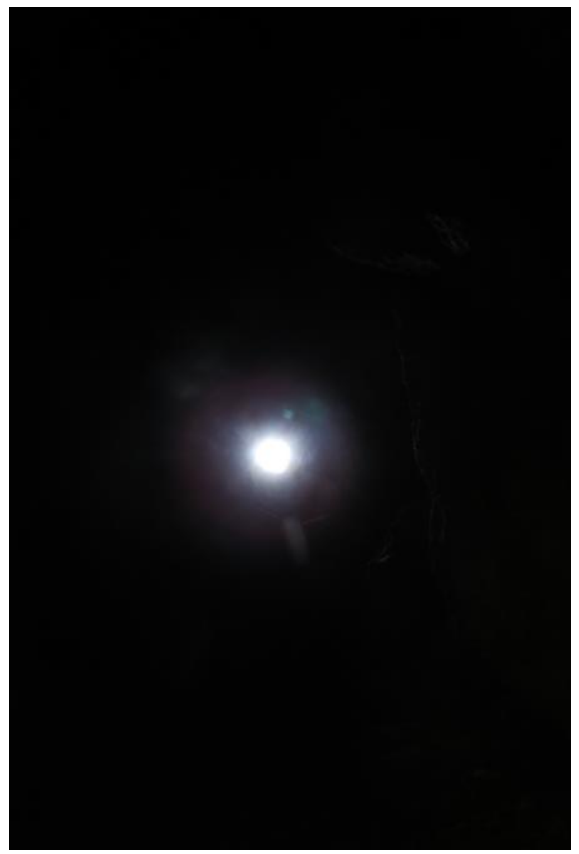


The cosmologies of pre-state societies, which all over the world are usually characterized by the absence of a clearly structured social hierarchy, are frequently if not universally based on the shamanistic model of ritual behavior and belief in multiple realms of existence that can be accessed through ASCs. Ample anthropological evidence illustrates the almost universal belief in a tripartite world, in which the middle world is the world of the living while the upper and lower realms are inhabited by supernatural creatures and ancestors (Eliade, 1951: 259-279; Lewis-Williams, 2010: 162-164). People who are able to access the upper and the lower realms (represented in the monotheistic religions by heaven and hell) can be found in virtually every pre-state society (Lewis-Williams, 2002a: 144). For instance, Bourguignon has shown in her research that at least $90 \%$ of 437 such societies surveyed by her possess one or more rituals dealing in one way or another with ASCs (Bourguignon, 1973: 9-11). Shamans, who are better equipped to achieve them, may constitute a smaller or larger part of the general population, but the rituals cannot be performed without their participation. Being a shaman demands special training and initiation rites, and possibly a certain personal genetic predisposition to this kind of activity. However, even for a trained person ASCs are not always easy to achieve. Therefore, shamans in different cultures use different techniques that we may call "triggers", which can help to achieve and intensify ASCs: dancing, psychedelic drugs, prolonged fasting and lack of sleep, severe pain, and many others or combinations of them (Eliade, 1951). One of the most effective "triggers" is sensory deprivation, which can be most easily experienced (along with general disorientation in space and time) in deep and absolutely dark caves while in complete isolation from the rest of the community. Therefore, we may propose that this was the reason why caves played such an important role in the life of prehistoric societies; descending into the dark and narrow passages of the karstic caves helped the shamans to induce ASCs and to reenact the experience of hallucinating (Lewis-Williams, 2002b: 101-102).

The elusive nature of the shamanistic ritual per se is unlikely to leave any direct archaeological evidence for the states of trance entered by shamans. Circumstantial evidence, however, may be provided by representations of dancing and processions found in various prehistoric sites (Garfinkel, 2003: 85-99), which may represent shamans experiencing ASCs. Archaeological evidence related to these practices is in general highly fragmentary in nature (Skeates, 2007: 90), and the ritual deposits discussed in this paper may be the only archaeological data discovered so far that can be interpreted as testimony to rituals repeated in the same remote parts of these caves and reflecting "a widespread perception of the underworld as an ambiguous liminal boundary and point of contact with 'the other world' " (Skeates, 1991: 121-129). Understanding the caves as liminal places of the oikumene of the living allows us to understand the deposition of valuable objects in hidden locations in the immediate vicinity of the border of their world as a statement of passage, similar to the garments left by Inanna on her way to the Netherworld. This perception of the dark and narrow cave passages as a metaphor for passage to a different realm may be even better illustrated by the personal experience of the archaeologist crawling through the cave (Tilley, 1994: 12). While doing this one can understand why such a space was the site of reenactment of the personal ASC experiences of a shaman, and at the same time the arena of social power where rites of passage took place (see below).

It may not be accidental that the appearance of ritual deposits in dark and deep caves, along with literary creations such as "Ištar's Descent and Resurrection", correlates with very significant developments in the burial traditions in our region in the late Neolithic and Chalcolithic periods. The bodies of the deceased, which had earlier been interred under the floors of dwellings, were now physically separated from the living: burials were concentrated in cemeteries located outside the settlements (Rowan \& Ilan, 2012; Nativ, 2014). The 
offerings accompanying the deceased to the Netherland constantly increased in number, and by the Early Bronze Age one can count hundreds of pottery vessels and other objects in tombs, such as those in Jericho (Kenyon, 1960: 1-180) or Bab edh Dhra (Schaub \& Rast, 1989). We see a clear tendency toward the use of caves for final interment of the remains of the dead. However, natural karstic caves do not occur everywhere in our region; in some areas, like the coastal plain, artificial caves were dug into the ground and used for burial. Such an investment of constantly increasing material resources in enterprises that had no functional significance for the economy of the community can be explained only by changes in religious doctrine and developments in the cosmological model of the local population of the Southern Levant in late prehistory. The problems of passage to the Netherworld and of subsistence in an individual's afterlife must have concerned the members of society, and as a consequence distant places on the fringes of the social and physical landscape, where "chthonic forces of death" (Rowan \& Ilan, 2012: 103) could be contacted, attracted increasing amounts of social power, concentrating them deep under the surface of the inhabited land. In fact, these artificial and natural mortuary caves and caves with ritual deposits seem to be very similar in function and meaning in late prehistoric society, the only difference being the absence of burials in the latter.

\section{CONCLUSIONS}

We may now propose a relationship between shamanistic rites of passage and the caches found in caves such as the Zarda cave (Whitehouse, 2007: 104), based on the following considerations:

1. As mentioned above, deposits placed in such dark and barely accessible places cannot be explained in functional terms. The only acceptable explanation, based on the neurobiological aspect of the shamanistic cult, is that these caches were ritual in nature.

2. The votive character of some of the pottery vessels found in the caves is also best explained by the ritual nature of the activity that led to their deposition.

3. The correlation between the introduction of natural or artificial caves as the main type of burial in the Southern Levant and the appearance of ritual deposits in the dark caves may be not accidental. As shown above, these two phenomena actually represent two sides of the same cosmological ideology and testify to the same belief in the individual's ability to pass into different realms of existence. The difference between the two is that while the former is evidence for the "one-way ticket" that all members of society will inevitably experience once in a lifetime as the final and ultimate rite of passage, the latter is evidence for rites of passage experienced by a few exceptional people who were able to reenact this ritual time and again.

4. Deposits of this kind can be seamlessly integrated into the generalized cosmological model of traditional shamanistic societies in different parts of the world.

5. The archaeological data presented in this paper correlates well with references to the rites of passage of visitors to the Netherworld that appear in Mesopotamian texts, particularly the items of clothes and personal adornment left in the gateways on the way down.

Therefore, the overall mass of archaeological and textual evidence enables us to propose a model of ritual behavior that is deeply embedded in the social structure of the ancient Near East and beyond. The rapid development of social complexity in late prehistory was embodied in focal points in the social landscape that attracted exceptional amounts of community resources and created arenas of social power in caves located far from the centers of community space. The deep and remote rooms and passages of such caves, shrouded in 
perpetual darkness, were located at the fringes of the physical landscape of the community and hence were natural candidates to become the scene of rites of passage. These factors, in themselves very powerful, were greatly intensified by the ability of the human brain to experience altered states of consciousness, following the exposure of selected members of society to sensory deprivation caused by the lack of visual and auditory stimuli that is characteristic of deep caves. Hallucinations induced within the brain were mixed with the actual experience of crawling through the dark, narrow and dangerous passages, translated in the minds of the participants into passage through the openings leading to the Netherland and creating a religious experience of unparalleled intensity. These experiences were so deeply embedded in the communal and cultural memory (Assmann, 2008) that their traces can be found even today in virtually every culture in the form of sacred caves and different kinds of oral and written traditions related to them.

\section{ACKNOWLEDGMENTS}

M. Frumin, T. Rogovsky, S. Shipitsin, A. Shavit, E. Bereza, L. Feigin, Y. Svortzov, M. Ullman, R. Porat, B. Langford, A. Frumkin, B. Zissu, U. Davidovich, D. Raviv.

\section{REFERENCES}

Assmann, J. (2008). Communicative and Cultural Memory. In Erll, A.; Nünning, A. (eds.) Cultural Memory Studies. An International and Interdisciplinary Handbook (pp. 109-118), Berlin.

Beckman, G. (2013). Intrinsic and Constructed Sacred Space in Hittite Anatolia. In Ragavan D. (ed.). Heaven on Earth. Temples, Ritual and Cosmic Symbolism in the Ancient World (pp. 153-175), Chicago: The Oriental Institute of the University of Chicago.

Ben-Ami, D. (2008). Monolithic Pillars in Canaan: Reconsidering the Date of the High Place at Gezer. Levant 40: 17-28.

Bourguignon, E. (1973). Religion, Altered States of Consciousness, and Social Change, Columbus, Ohio State University Press.

Chapman, J. (1991). The Creation of Social Arenas in the Neolithic and Copper Age of South East Europe: The Case of Varna, In Garwood, P.; Jennings, P.; Skeates, R.; Toms, J. (eds.) Sacred and Profane (pp. 152-171). Oxford: Oxbow.

Clottes, J. and Lewis-Williams, D. (1998). The Shamans of Prehistory. Trance and Magic in the Painted Caves. New York: Harry N. Abrams.

Cook, A. (1925). Zeus. A Study in Ancient Religion. Volume II. Cambridge: University Press. Eliade, M. (1951). Shamanism. Archaic Techniques of Ecstasy. New York, Follingen Foundation.

Ellis, R. (1968). Foundation Deposits in Ancient Mesopotamia. New Haven: Yale University Press.

Garfinkel, Y. (2003). Dancing at the Dawn of Agriculture. Austin: University of Texas Press. Garfinkel, Y. and Ben-Shlomo, D. (2009). Sha'ar Hagolan 2. The Rise of Urban Concepts in the Ancient Near East. Qedem Reports 9. Jerusalem: The Hebrew University of Jerusalem and Israel Exploration Society.

Gopher, A and Tsuk, T. (1996). The Nahal Qanah Cave. Earliest Gold in the Southern 
Levant. Tal Aviv: Sonia and Marco Nadler Institute of Archaeology Publications.

Hazzidakis, J. (1913). An Early Minoan Sacred Cave at Arkalokhori in Crete. Annual of the British School at Athens 19: 35-47.

Jones, D. (1999). Peak Sanctuaries and Sacred Caves in Minoan Crete. Jonsered: Paul Áströms förlag.

Kenyon, K. (1960). Excavations at Jericho. Volume One. The Tombs Excavated in 19521954. London: The British School of Archaeology in Jerusalem.

Langford, B., Frumkin, A. and Zissu, B. (2011). The Discovery of the Abud Cave. In the Highland's Depth 1: 69-77 (Hebrew).

Lapinkivi, P. (2010). The Neo-Assyrian Myth of Istar's Descent and Resurrection. State Archives of Assyria Cuneiform Texts. Vol. VI, Winona Lake.

Leroi-Gourhan, A. (1984). L’art des Cavernes. Atlas des Grottes Ornées Paléolithiques Françaises. Paris. Ministère de la Culture.

Lewis-Williams, D. (2002a). The mind in the Cave. London: Thames and Hudson.

Lewis-Williams, D. (2002b). A Cosmos in Stone. Interpreting Religion and Society through Rock Art. Walnut Creek: Alta Mira Press.

Lewis-Williams, D. (2010). Conceiving God. The Cognitive Origin and Evolution of Religion. London: Thames and Hudson.

Macalister, R.A.S. (1911). The Excavation of Gezer. Volume I. London: Committee of the Palestine Exploration Fund by J. Murray.

Macalister, R.A.S. (1912). The Excavation of Gezer. Volume II. London: Committee of the Palestine Exploration Fund by J. Murray.

Moyes, H. (2012). Sacred Darkness. A Global Perspective on the Ritual Use of Caves. Boulder: University Press of Colorado.

Nativ, A. (2014). Prioritizing Death and Society. The Archaeology of Chalcolithic and Contemporary Cemeteries in the Southern Levant. Durham: Acumen.

Neuville, R. (1930). Notes de Préhistoire Palestinienne. Journal of the Palestine Oriental Society 10: 64-78.

Rowan, Y. and Ilan, D. (2012). The Subterranean Landscape of the Southern Levant during the Chalcolithic Period. In Moyes H. (ed.). Sacred Darkness. A Global Perspective on the Ritual Use of Caves. Boulder: University Press of Colorado. Pp. 87-109.

Shanon, B. (2002). The Antipodes of the Mind. Oxford: Oxford University Press.

Schaub, R. and Rast, W. (1989). Bâb edh Dhrâ'. Excavations in the Cemetery Directed by Paul W. Lapp (1965-1967). Winona Lake: Eisenbrauns.

Sieveking, A. (1979). The Cave Artists. London: Thames and Hudson.

Sireteanu, R., Oertel, V., Mohr, H., Linden, D., Singer, W. (2008). Graphical illustration and functional neuroimaging of visual hallucinations during prolonged blindfolding: a comparison to visual imagery. Perception 37: 1805-1821.

Skeates, R. (1991). Caves, Cult and Children in Neolithic Abruzzo, Central Italy. In Garwood P., Jennings D., Skeates R. and Toms J. (eds.). Sacred and Profane: Proceedings of a Conference on Archaeology, Ritual and Religion (pp. 122-134). Oxford: Oxford University Committee for Archeology. 
Skeates, R. (2007). Religious Experience in the Prehistoric Maltese Underworld. In Barrowclough D. and Malone C. (eds.). Cult in Context. Reconsidered Ritual in Archaeology (pp. 90-97). Oxford: Oxbow Books.

Tilley, C. (1994). A Phenomenology of Landscape. Places, Paths and Monuments. Oxford: Berg Publishers.

Ustinova, Y. (2009). Caves and the ancient Greek mind: descending underground in the search for ultimate truth. Oxford: Oxford University Press.

Van Buren, (1931). Foundation Figurines and Offerings. Berlin: Hans Schoetz \& Co.

Van Gennep, A. (1960). The Rites of Passage. Chicago: University of Chicago Press.

Van de Noort, R. (2008). The Archaeology of Wetland Landscapes: Method and Theory at the Beginings of the $21^{\text {th }}$ Century. In David B. and Thomas J. (eds.) Handbook of Landscape Archaeology (pp. 482-489). Walnut Creek: Left Coast Press.

Whitehouse, R. (2007). Underground Religion Revisited. In D. Barrowclough and C. Malone (eds.), Cult in Context. Reconsidering Ritual in Archaeology (pp. 97-107). Oxford: Oxbow Books.

Zissu, B., Langford, B., Porat, R., Raviv, D. and Frumkin, A. (2014). An Archaeological Survey of the Elqana Cave in Western Samaria. In the Highland's Depth 4: 15-31 (Hebrew). 